\title{
Women in Politics by Bass Diffusion Model
}

\author{
Marino A. Garcia, Chrysler M. Cabusa \\ Cebu Normal University, Cebu City, Philippines \\ Email: garciam@cnu.edu.ph, cabusac@cnu.edu.ph
}

How to cite this paper: Garcia, M. A., \& Cabusa, C. M. (2020). Women in Politics by Bass Diffusion Model. Open Journal of Social Sciences, $8,280-286$. https://doi.org/10.4236/jss.2020.811025

Received: October 4, 2020

Accepted: November 24, 2020

Published: November 27, 2020

Copyright (c) 2020 by author(s) and Scientific Research Publishing Inc. This work is licensed under the Creative Commons Attribution International License (CC BY 4.0).

http://creativecommons.org/licenses/by/4.0/

Open Access

\begin{abstract}
Gender equality through women empowerment has been a global advocacy since the early $20^{\text {th }}$ century. This paper attempts to forecast the participation of women in politics, especially in the Philippines. Data from 1998 to 2016 on the number of women joining the Philippine government (elected) were extracted from the Philippine Statistics Authority. The data were used to denote the cumulative adopters by tailoring it to the Bass diffusion model by means of the Bass Forecasting Spreadsheet. It was found out that the adoption rate in 2040 will be around $37 \%$ in the present population. This means that women role in politics is expected to reach its peak based on the first data in 42 years. The use of this model delivered an idea that the growing nature of women in the politics either from local and national positions can seemingly sustain overtime. Further, it denotes that even in the increasing involvement of women in politics, there will be a time that it reaches its saturation point. In the same vein, even with the saturation, the years mark and uncover the significant contributions of women in the politics. Hence, it is not the quantity of women in the Philippine politics that matters, but rather the kind of service they can provide to uplift the quality of Filipino lives.
\end{abstract}

\section{Keywords}

Women, Politics, Bass Diffusion Model, Gender Equality

\section{Introduction}

The role of women in the country has been acknowledged by the Philippine Constitution such as in promoting the gender equality among men and women and abiding the law by stating the significant contributions of women in nation building. In the same vein, the augmentation of the functions of women in the society as reflected in giving fair and equal footing in making decision and policy either in government or private entities has been covered in Section 11 of the Magna Carta of Women (MCW). Hence, in the new era of politics and govern- 
ment, women are increasingly noticeable in holding government functions in the office. Women today have been recognized in their distinct capacity and innate talents in terms of leadership and policy-making. For the last two decades, the growth and representation of women in government and politics in the global arena has dramatic increased from 11.8 percent in 1998 to 17.8 percent in 2008 to 23.5 percent in 2018 (womendeliver.org, 2018). According to the National Democratic Institute, Africa (13.7\% to $19.8 \%)$ and Arab state region $(6.1 \%$ to $14.7 \%$ ) have shown sky rocketed increase in the involvement of women in the parliaments. Unfortunately, the astonishing increase of the women in parliaments did not remarkably show that women have achieved the "critical mass" of representing the world of politics in the globe. However, women today are well motivated and courageous to affiliate in government functions incognizant of the many success stories of the women in the field. Although, Sustainable Development Goals of 2030 fortifies Gender Equality in ending all forms of discrimination against women and giving equal access to opportunity in the world.

Studies indicate that women as legislator represents not only for women per se but for the improvement of policy to responsive especially to the marginalized and less privilege individual. Thus, elected women in office alleviate the quality of life and reflect the priorities for all the families, women, and ethnic and racial minorities (Volden, Wiseman, \& Wittmer, 2010). Rosenthal (2001) explained that women function much better than men in terms of leadership, conflict resolution styles, participation, and collaboration and women are known less hierarchical in work. Thus, women always proved to stay calm even in a very difficult situation and exceptionally listen attentively to the call of peace making. The Institute for Inclusive Security (2009) indicates women being part of peace processes can probably increase the level of peace stability, lessen corruptions, and exemplify health care and education in the community.

The necessity in understanding women is utmost significant especially in forecasting the trend in the participation of women in politics since women play an important role in nation building. Hence, the participation of women in politics can't be taken for granted since year by year the augmentation is conspicuous. Using the Bass Diffusion model as the representation of diffusive adoption, the study then predicts the saturation of women participation in politics with respect to time and provide basis in program implementation related to gender equality and/or women empowerment.

\section{Methodology}

An 18-year data, from 1998 to 2016, on the number of women joining the Philippine government (elected) from 1998 to 2016 was extracted from the Philippine Statistics Authority which can be accessed publicly on the website of the agency. These were the official number of elected officials for 18 years national elections which was amounting to 17,941 women in politics. The data were used to represent the cumulative adopters by tailoring them to the Bass diffusion 
model (Bass, 1963) using Microsoft Excel spreadsheet. The number of new adopters was graphed to forecast the diffusion of women participation in politics for the coming years. At the same time, another graph on the cumulative diffusion was also generated. The graphs were the bases in generating the analysis of the data wherein the insights and estimations were derived.

\section{Results}

The participation of women from 1998-2016 was tailored into the Bass diffusion model. The transformation in the participation of women gives in to the pattern of diffusive adoption that imitates the exponential capacity of men in the politics.

Figure 1 reveals that all the way through the years the number of cases will remarkably increase. It forecasts that the adoption rate in 2040 will be around $37 \%$ of the present population. Surprisingly, in around 2015 to 2016, there is a piercing increase in the participation of women in the politics which can be contributed to the promotion of Gender Equality in the world. Intensive and serious propagation of this goal-Gender Equality has indeed alleviates the participation of women which have been felt not only in politics but in different functions and roles in the society that merits on their contributions and attributions to the growing population of the world. Hence, the participation of women increases in politics, it is in the same way telling that the quality of life of the people progressed (Voden et al., 2010).

Figure 2 shows that the participation of women is estimated to peak in the year 2040, 42 years after the first data or more than 4 decades after. This is quite alluring on the kind of role that the women play in the world of politics. Even though the noticeable effort of the women in politics can be seen and felt, it will continue to saturate in the level wherein another adapter will push its limits and thrive again to gain its force to move forward and flourish.

Figure 3 shows the potential market penetration of women participation in

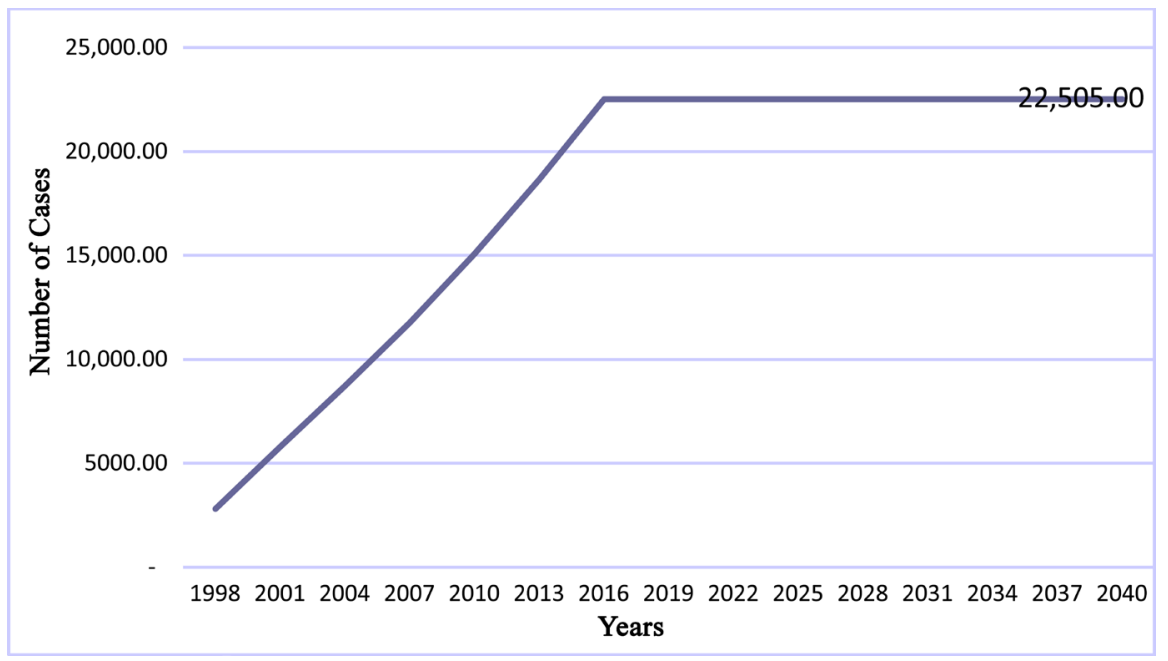

Figure 1. Cumulative adapters. 


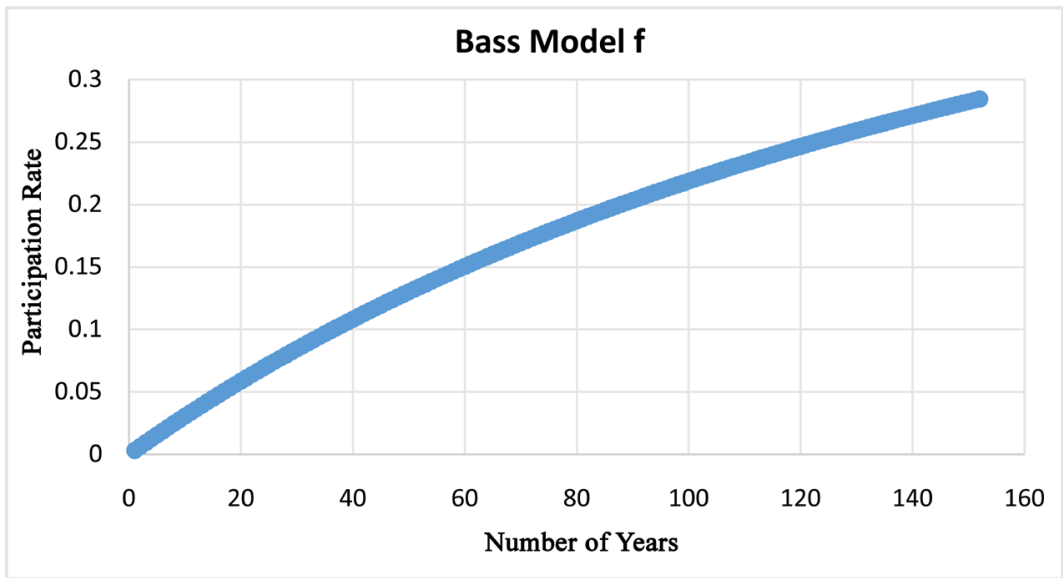

Figure 2. Bass model.

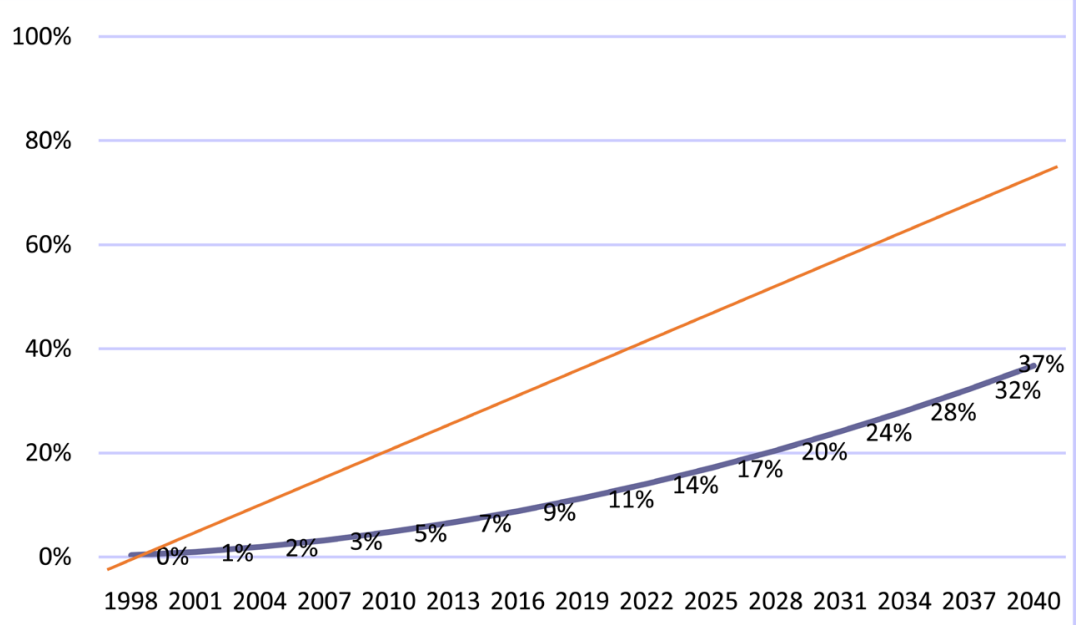

Figure 3. Potential market penetration.

politics as shown in the difference between the Bass Model and the existent women in politics. The standard error of prediction is 0.04888763 which presents a similitude between the two. The capability values produced in the model were used as basis for the line graph. The graph was used to tell the saturation point of the data set. The said point was used as indicator of the diffusion stage. This stage is where the social atoms adopt the emerging behavior accumulated over time. Likewise, a model using the participation of women in politics can be used to yield numbers that are nearer to factual data. Thus, the reason of the studying politics in general uses such a mathematical model.

\section{Discussion}

The participation of women over the years has brought dramatic and historical declaration of noble and courageous steps for their voices to be heard and uplift their rights. Thus, women nowadays tend to get involved in politics. Women lawmakers has the eye to see the social issue about women broadly since traditionally women are mothers and caregivers of the community which in a way 
perceived community concerns as sensitive and more responsive in the need of the community (O'Connor, Undated; Camissa \& Reingold, 2004).

The results showed that women participation in politics just registered 37\% when forecasted up to 2040. This augmentation of the women as political leaders is solid evidence that indeed gender equality in the country and around the world is definitely observed and practiced. Similarly, women as public servants provide fresh ideas on political and social matters contributory to policy making (Smee \& Woodroffe, 2013). However, even when empowered, women will still be outnumbered by men in terms of participation in the Philippine government. Such forecast can be supported by history which revealed the dominance of men in terms of leadership and governance. In the old culture, the hierarchy in terms of power and decision making is delivered from the father which place the wife at the expense of following the husband without unnoticed hesitation (Xie, 1994) while in the modern world the inverse relationship in terms of gender roles, family responsibility and economic provision is dominantly noticeable (Oláh, Richter, \& Kotowska, 2018). However, in the latest report on the Millennium Development Goals in 2019 presents that there is an increase participation of women in parliamentary matter (ONU, 2019). Moreover, other women perhaps thought of empowerment in other areas such as nursing, home economics, or have managerial positions in either public offices or private firms.

People are born free and equal in dignity and rights in which equality and non-discrimination must be observed regardless of status, gender and race (Huh, 2020) and equality before the law warranty true identity (Navarro, 2017). Thus, women inequity issue can be reduced when women strengthened their involvement and participation in any capability building and opportunities to showcase their potentials in different fields and in politics (Lanterna, Rosas, Delfino, \& Rosaroso, 2018). Indeed, this study provides that women in this year and in the coming years can take a lead in political discourse and position to show and broadcast across the globe that woman can work hand in hand or at par with men in terms of politics.

\section{Conclusion}

The expenditure of using the model of Bass diffusion delivered an idea that the collective nature of women in the politics can seemingly sustain overtime. This gives a thought that even in the increasing participation of women in politics, there will be a time that it reaches its saturation point. This model does not provide the different factors that contribute to the desire of women in engaging in the world of politics. Though, it proves that women can lead and execute in the ups and downs of the so-called public service-politics.

\section{Recommendations}

In the study, it is recommended to conduct a study of actual interaction of women in politics in terms of their involvement, motivation, aspiration, desire, 
and obligation. Thus, it is recommended to strengthen the implementation of gender equality in the country to foster a strong nation by accounting the contribution and building the culture of women empowerment in the country and across the globe. Further, the results can be used in crafting programs, guidelines, and regulations in promoting and encouraging women to actively participate in the world of politics.

\section{Conflicts of Interest}

The authors declared no potential conflicts of interest with respect to the research, authorship, and publication of this article.

\section{References}

Bass, F. M. (1963). A Dynamic Model of Market Share and Sales Behavior. Proceedings, Winter Conference American Marketing Association, Chicago, 269.

Camissa, A., \& Reingold, B. (2004). Women in State Legislators and State Legislative Research: Beyond Sameness and Difference. State Politics and Policy Quarterly, 4, 181-210. https://doi.org/10.1177/153244000400400204

Huh, R. K. (2020). Revisiting Feminist Care Ethics for the Age of the "Pluralistic Family". Asian Journal of Women's Studies, 26, 22-35. https://doi.org/10.1080/12259276.2020.1718365

Lanterna, S. F., Rosas, F. G., Delfino, M. E., \& Rosaroso, R. (2018). A Woman in Politics: The Journey of Ms. X. Asia Pacific Journal of Multidisciplinary Research, 6, 25-30.

Magna Carta of Women (2009). Rights and Empowerment. https://cws.up.edu.ph/wp-content/uploads/RA-9710-Magna-Carta-of-Women.pdf

National Democratic Institute (n.d.). Why Women in Politics? https://www.google.com/search?q=women+in+politics+studies\&oq=women+in+politi $\underline{\text { cs+studies\&aqs }=\text { chrome } .69 \mathrm{i} 57.24501 \mathrm{j} 0 \mathrm{j} 7 \& \text { sourceid }=\text { chrome } \& \mathrm{ie}=\mathrm{UTF}-8}$

Navarro, M. (2017). La Igualdad De Género Como Derecho Humano: Un Análisis Desde La Perspectiva Del Derecho Internacional En El Ámbito Laboral. Quito: Editorial Jurídicadel Ecuador.

O'Connor, K. (Undated). Do Women in Local, State, and National Legislative Bodies Matter? The Women and Politics Institute, American University.

Oláh, L., Richter, R., \& Kotowska, I., (2018). The New Roles of Men and Women and Implications for Families and Societies. In G. Doblhammer, \& J. Gumà (Eds.), A Demographic Perspective on Gender, Family and Health in Europe (pp. 41-64). Cham: Springer.https://doi.org/10.1007/978-3-319-72356-3_4

ONU (2019). The Millennium Development Goals Report 2019. Sustainable Development Goals Report 2019.

https://unstats.un.org/sdgs/report/2019/The-Sustainable-Development-Goals-Report-2 019.pdf

Rosenthal, C. S. (2001). Gender Styles in Legislative Committees. Women \& Politics, 21, 21-46. https://doi.org/10.1300/J014v21n02_02

Smee, S., \& Woodroffe, J. (2013). Achieving Gender Equality and Women's Empowerment in the Post-2015 Framework. The Gender and Development Network.

http://www.gadnetwork.org.uk

Sustainable Development Goals of 2030. https://www.sdgfund.org/goal-5-gender-equality 
The Institute for Inclusive Security (2009). Strategies for Policymakers: Bringing Women into Government.

Volden, C., Wiseman, A. E., \& Wittmer, D. E. (2010). The Legislative Effectiveness of Women in Congress.

Xie, D. Y. (1994). Divergence in Economic Performance: Transitional Dynamics with Multiple Equilibria. Journal of Economic Theory, 63, 97-112.

https://EconPapers.repec.org/RePEc:eee:jetheo:v:63:y:1994:i:1:p:97-112

https://doi.org/10.1006/jeth.1994.1034 